\title{
How is Wuthering Heights a Gothic Novel?
}

\section{Weirong Qiao}

School of Foreign Languages, Shandong University of Technology, Shandong, China, 255000

Email: 17450147@qq.com

\begin{abstract}
This article aims to explore the Gothic features of Emily Bronte's Wuthering Heights. The Gothic novel as a genre reached its peak in Emily Bronte's childhood and Emily was greatly influenced by Gothic novels. Emily Bronte managed to make her only novel, Wuthering Heights, a Gothic one by creating wild and dark characters, creepy environment, uncanny plots and supernatural scenes, which are important elements in most Gothic novels.
\end{abstract}

Keywords-Emily Bronte, Gothic Features, Gothic Novels, Wuthering Heights.

\section{INTRODUCTION}

The Victorian period was the climax of the British industrial revolution, the peak of the British social, political, economic and cultural development, and the heyday of the novels after romanticism. Amid the hustle and bustle of the industrial age, the wild and barbarian feel in Wuthering Heights is so lonely and distinguished. When Emily wrote Wuthering Heights, the golden age of Gothic fiction has been long gone. Living on a remote moor, Emily Bronte abandoned the mainstream of English literature at the time and became world famous with the gloomy and ghastly gothic novel is legendary in its own right.

The northern moors in England provide the setting of Wuthering Heights, where the romance of Heathcliff and Catherine happen and become known by the whole world. Emily Bronte devoted great effort in her only novel, though criticized and despised by many on its first publish, loved and appreciated by readers throughout the world with time going because of its depiction of the darkness in humanity, the unbelievable romance accompanied by revenge, and the uncanny plots and supernatural scenes which grasp every reader. Why is Wuthering Heights a Gothic novel will be explored in the following article.

\section{ORIGIN OF GOTHIC NOVELS AND GOTHIC NOVELS AS A GENRE}

Originating in France in the 12th-century, Gothic architecture was widely used, especially for cathedrals and churches, until the 16th century. As a style that flourished in Europe, it has a special historical and cultural color. Being dark, terrifying, and mysterious, this type of architecture provides unlimited horrible and thrilling imagination. Tall against the sky, while ornate and intricate in its style, Gothic architecture seems to be the ideal backdrop for both the physical and the psychological settings in a new literary genre, which concerned itself with elaborate stories of horror, mystery, and suspense. Most of the stories take place inside of castles, and they normally either contain significant supernatural elements or they hint at potential supernatural occurrences that are later explained.

The Castle of Otranto, a novel by Horace Walpole, was published in 1764. In the second edition, Walpole applied the word 'Gothic' to the novel in the subtitle - "A Gothic Story". The novel combines medievalism and terror in a style that has endured ever since. It is considered the first Gothic novel, and it is often said to have founded the horror story as a literary genre.

Some of the most influential and popular 18th-century Gothic writers were Horace Walpole ("The Castle of Otranto," 1764), Ann Radcliffe ("Mysteries of Udolpho," 1794), Matthew Lewis ("The Monk," 1796). The genre continued to appeal to a large number of readers well into the 19th century, first as Romantic authors such as Sir Walter Scott ("The Tapestried Chamber," 1829) adopted Gothic conventions, then later as Victorian writers such as Robert Louis Stevenson ("The Strange Case of Dr. 
Jekyll and Mr. Hyde," 1886) and Bram Stoker ("Dracula" 1897) incorporated Gothic motifs in their stories of horror and suspense. Elements of Gothic fiction are prevalent in several of the acknowledged classics of 19th-century literature, including Mary Shelley's "Frankenstein" (1818), Nathaniel Hawthorne's "The House of the Seven Gables" (1851).

\section{GOTHIC NOVELS AND EMILY BRONTE}

\subsection{Gothic Novels in the Victorian Context}

In the Victorian era, the era of Emily, realism began to take the lead in literature. Like the Romatic school, the position of Gothic novels has been greatly lowered. Some said the Gothic novels had been dead and they had come back to life, which is not contradictory. Mary Shelley's "Frankenstein", originally written in the classical era, whose artistic charm has never faded since it was regarded as the peak of Gothic novels. The death of Gothic novels is not that they are not competitive, but because too many follow the suit and took the genre, too much imitation, excessive sex and violence, which made the fresh genre vulgar and superficial.

The opening of new times has brought new vitality to Gothic novels. Robert Mighall sees the urban Gothic as a genre arising in London in the mid-nineteenth century out of the critique of the impact of industrialization. Charles Dickens is one of the greatest critical realist writers of the Victorian Age. His novel, A Tale of Two Cities, opens with "It was the best of times, it was the worst of times, it was the age of wisdom, it was the age of foolishness, it was the epoch of belief, it was the epoch of incredulity, it was the season of Light, it was the season of Darkness, it was the spring of hope, it was the winter of despair..." In such times, the Gothic stories happen in the booming industries rather than distant Middle Ages or Renaissance, in modern metropolises, dirty slums, and orphanages rather than in ancient mysterious castles, churches, and monasteries. The traditional conflict between good and evil can be seen in Dickens' Oliver Twist, Bleak House, and other works. In his novels, we can see weak young girls and shameless villains, which are typical characters in traditional Gothic novels. Sharp social criticism combined with the Gothic tradition, Dickens depicts the hypocrisy of all classes, the struggle of ordinary miserable life, the cruelty and ugliness of the society, and truth, goodness, beauty, and humanity.
The Bronte sisters were influenced by such times, too. They have their own special understanding of Gothic novels and integrated Gothic elements with reality and became the most well-known female writers of Victorian era. The childhood of the Bronte sisters witnessed the popularity of those Gothic writers like Mary Shelley. Among what they read, there were also Blackwood's Edinburgh Magazine, The Edinburgh Review, and Fraser's Magazine, which contained lots of tense, horrible while exciting stories.

Jane Eyre by Charlotte Bronte is obviously influenced by Gothic novels: villain-hero Rochester, bloodcurdling screams, insane woman in the attic, attempted bigamy conspiracy, etc. Set in a real world, Wuthering Heights adopted many Gothic elements, among which the Gothic theme is the most evident one: revenge and property inheritance. After being robbed of love by Linton, Heathcliff left and devoted himself to planning his revenge, since which has been the only purpose of his living. He tortured Linton by contacting Catherine constantly and his own son by forcing him to marry Catherine the junior, only to get Thrushcross Grange. Revenges and fighting for inheritance are themes of traditional Gothic novels.

In Wuthering Heights, Emily created a typical Gothic character, the villain hero Heathcliff, and also a typical Gothic female character Isabella. All the criteria of good and evil in the real world had lost their values for Heathcliff, sometimes depressed and gloomy, sometimes fiery and brutal, he was treated unjustly while was distorted by the revenge. His evilness was not in his nature, but caused by his origin and the environment. The revenge he put into force was extremely devastating and rebellious. Isabella is pure, innocent, romantic, and totally helpless when she was maltreated. Being beautiful, sensitive, and naive, she was seduced, caged and tortured by Heathcliff. She finally escaped and raised her son by herself, died miserably and sacrificed for Heathcliff's revenge.

The gloomy and horrible color of the Gothic story is manifested in different ways. Dreams are mentioned throughout Wuthering Heights by Emily Bronte, but the dreams that stand out the most are the pair of nightmares that Lockwood has on the night he spends at Wuthering Heights. The scary ghost, the bloody hand, the broken window and the pale face outside all contribute to the uncanny atmosphere Emily created. After Catherine's death, Heathcliff's craziness, digging of her tomb and longing for being buried together with Catherine all stimulate the readers' 
nerves. At the end of the novel, some supernatural phenomenon like the wandering ghosts of the couple is also created to pile on the Gothic color.

What Emily Bronte wants to present to the reader, however, is much more than the Gothic elements used throughout the novel. Being realistic, romantic and naturalistic, Emily is dedicated to telling a story with strong feelings and drawing resonance with the readers. Emily never got married, while she yawns for love, or she wouldn't have created Wuthering Heights. Like Charles Dickens in the same era, Emily Bronte uses the elements of the old traditional Gothic novels yet depicts deeper feelings and strong emotions for a higher purpose.

\subsection{Autobiographical Factors in Wuthering Heights}

Wuthering Heights and Jane Eyre experienced quite different destinies. The publishing of Jane Eyre has been a big hit and has been praised and interpreted by many. While Wuthering Heights remained obscure in Emily's lifetime. The only attention it drew was negative criticism. The gloomy setting, the barbarian, sick, and distorted character in the novel could hardly draw resonance. Reviewers implied that the author of such a novel must be insane, obsessed with cruelty and barbarity. "Here all the faults of Jane Eyre are magnified a thousand fold, and the only consolation which we have in reflecting upon it is that it will never be generally read." [1] "This is a strange book. It is not without evidences of considerable power: but, as a whole, it is wild, confused, disjointed, and improbable; and the people who make up the drama, which is tragic enough in its consequences, are savages ruder than those who lived before the days of Homer ..." [2] The novel shined only years after Emily's death.

From the wilderness, the rough and capricious characters in the works, we could see clue of the author's childhood. Her father, Patrick Bronte, was an Anglican clergyman. He moved his family to Haworth amid the Yorkshire moors in 1820. After the death of their mother in 1821, Emily and her siblings were left very much to themselves in the bleak moorland. Emily describes the loneliness of the moor in her poem:

A heaven so clear, an earth so calm,

So sweet, so soft, so hushed an air;
And, deepening still the dreamlike charm,

Wild moor-sheep feeding everywhere. [3]

Patrick Bronte was a withdrawn man who dines alone in his own room. Like her father, Emily seems to have preferred a quiet, reclusive life. Such quietness was preferred by characters in her Wuthering Heights, too, as a character in her novel writes: "I'm now quite cured of seeking pleasure in society, be it country or town. A sensible man ought to find sufficient company in himself." (Lockwood, Wuthering Heights, 1847) Emily was educated mostly at home, and when her brother Patrick was given some wooden soldiers as a gift, the siblings began to make up stories about the world that the soldiers lived in. They wrote the stories in tiny script, in books small enough for the soldiers and also provided newspapers and poetry for the world they apparently first called Glasstown. Emily and Anne had small roles in these tales. Emily and Anne had created a kingdom themselves, and later created another, Gondal. The situation was very much like the early life of Heathcliff and Catherine' in the novel too. The beautiful wild life they enjoyed on the boundary-less moors seems to be the sweetest memories in both of their life. In the novel, Catherine describes her love for Heathcliff: "My love for Linton is like the foliage in the woods: time will change it, I'm well aware, as winter changes the trees. My love for Heathcliff resembles the eternal rocks beneath: a source of little visible delight, but necessary." (Catherine, Wuthering Heights, 1847) As children, Catherine and Heathcliff spend their days running together on the Yorkshire Moors, a wet and wild expanse of land, symbolic of their own shared wildness and attraction to danger. As adults, they got involved in a tragic love triangle, the feelings of which they frequently describe in comparison to the tumultuous weather on the Moors.

In almost every Gothic novel, there exists a tyrannya hero villain. Rochester, the hero in Jane Eyre, a novel with Gothic characteristic by Charlotte Bronte, is quite positive and charming, but the mystery about him and his controlling desire made the readers admire and fear. Emily made fathers tyrannies. Between Heathcliff and Linton, there is not even a tiny affection. On the first sight of his son, Heathcliff said he would care for him and educate him but he added, "I do regret, however, that he so little 
deserves the trouble: if I wished any blessing in the world, it was to find him a worthy object of pride; and I'm bitterly disappointed with the whey-faced, whining wretch!"(Heathcliff, Wuthering Heights, 1847) Compelled by revenge, Heathcliff tortured Linton's mother, and took back Linton after his mother's death, only to get the property of Thrushcross Grange. Heathcliff made Linton terrified, and with only one look at his son, he would made him shudder and subservient and do whatever Heathcliff asked him to, even to be part of his plan of revenge. Another example is Hindley Earnshaw, a bullying, discontented boy who grows up to be a violent alcoholic when his beloved wife, Frances, dies. In the novel Hindley grabs his own baby son and shouts, "I'll break the brat's neck", "Poor Hareton was squalling and kicking in his father's arms with all his might, and redoubled his yells when he carried him upstairs and lifted him over the banister." (Nelly, Wuthering Heights, 1847) The father then drunkenly drops him, and baby Hareton's life is only saved because Heathcliff manages to catch him.

Children in many novels either have weak mothers or lose their mothers in childhood, and their fates seem to be manipulated by their tyrannical fathers. We can see a clue of Emily Bronte's childhood from her novel. Emily lost her mother when she was quite young and the mothers died young and left their children helpless in her Wuthering Heights too: Catherine died only two hours after her delivering of her daughter, Frances died of tuberculosis soon after she gave birth to Hareton, and Isabella, died young and left her son to the cruel world of Hindley and Heathcliff. Emily's father, was an odd man who always dines alone in his study. "Mrs. Gaskell in the early editions of her biography of Charlotte Bronte, is that of a severe, ill-tempered, and distinctly disagreeable character." [4] Father being such, "She had, in the years when that was most essential, no mother's care; and perhaps there was a somewhat too rigid disciplinarian in the aunt who took the mother's place." [5]

The horrible scenes in Wuthering Heights are also partly influenced by such an irritable father. Patrick Bronte graduated from St. John's College, Cambridge. Being knowledgeable, he would tell his children of the Irish wild legends which brought up Emily's interest in mysterious and horrible stories. Ernst Eheodor Amadeus, was a
German Romantic author of fantasy and Gothic horror, who enjoyed similar childhood with Emily, drew strong resonance in Emily. "She wrote Wuthering Heights because she was impelled thereto, and the book, with all its morbid force and fire, will remain, for all time, as a monument of the most striking genius that nineteenth century womanhood has given us. It was partly her life in Yorkshire - the local colour was mainly derived from her brief experience as a governess at Halifax - but it was partly, also, the German fiction which she had devoured during the Brussels period, that inspired Wuthering Heights. '[6]

\section{GOTHIC FEATURES IN WUTHERING HEIGHTS}

Being dark, Gothic novels start an era of horror and ugliness as beauty of literature. This genre broadens the aesthetic standards and the manifestation styles of literature. They provide readers with hellish things and scenes, unbelievable evil personalities, thus make quite impressive memories in readers' mind, and provide an unforgettable experience of exploring. The "darkness" of Wuthering Heights once drew strong criticism but turned out to be attractive and charming. In this chapter, we'll display how the Gothic features are obtained in Wuthering Heights.

\subsection{Gothic factor in Character Building and Environmental Depiction}

There are different kinds of characters in Gothic novels, but the most striking and typical characters are the tyrannies, religion believers, fragile women and ghosts. The tyrannies are the most prominent and appear in most Gothic novels. They are cold, ruthless, and imperious and they are like evils because they will do virtually anything, be it moral or not, in order to get their purposes obtained. The dragon king Vathek from Vathek and Prince Manfred from The Castle of Otranto are just two examples. Vathek is a man who is addicted to sensory pleasures and indulges himself in black magic. He makes Nouronihar his companion in the pleasures of this world and the world of magic. He finds the secret lair of Eblis, Lord of Darkness, only to have his heart consumed by eternal flames.

The villains are a special creation of the British Gothic novels. They are often extremely handsome, intelligent, successful, talented, or charming, although there is usually 
some warning sign to warn us that their looks are deceiving. Gothic villains are both evil and alluring, and often pose as innocents or victims. Heathcliff in Wuthering Heights is doubtless such a villain, which made the novel controversial, and because his extreme behavior, he was hated and accused by many. "How a human being could have attempted such a book as the present without committing suicide before he had finished a dozen chapters, is a mystery. It is a compound of vulgar depravity and unnatural horrors...." [7], and some even suggest burning Wuthering Heights: "We rise from the perusal of Wuthering Heights as if we had come fresh from a pest-house. Read Jane Eyre is our advice, but burn Wuthering Heights...." [8] Charlotte Bronte, Emily Bronte's sister, says, when she writes the preface to Emily's novel, "Heathcliff never swerves once from his arrow-straight course to perdition", like he is going to hell from the beginning, she said. That shows what an unpleasant character is Heathcliff to Charlotte and to many other readers.

In contrast to Heathcliff, Isabella, like other Gothic weak women, is seduced and prisoned by Heathcliff, and falls a victim of his revenge plan. She was attempted by Heathcliff, dreamed of romantic love and eloped with him, ignoring others' warning. She paid great sacrifice to her ignorance: being prisoned, tortured, and escaped, died miserably far away from her warm home. Innocent but weak women are another typical characteristic of Gothic novels, often they are beautiful, pure, and when they are in adverse situation, they are usually helpless and desperate. Another lovely and virtuous damsel also named Isabella, in The Castle of Otranto, was threatened by kidnapping, rape, and an overall unwanted marriage, she tries to escape from the castle after the death of her intended husband, Conrad. She narrowly escapes Manfred's grasp, preventing a nearly incestuous and non-consensual marriage from taking place. In The Monk, Agnes, when her pregnancy was discovered by the Prioress of the convent, she is subjected to horrible punishments; Antonia, being completely innocent and naive, was given a drug and was seduced by the most revered monk in Madrid - Ambrosio, and tortured to death.

In addition to the typical Gothic characters, there are also the gloomy and horrible atmospheres which exist throughout the novel. The story happens on the harsh and uncultivated English moors. The setting, which is often depicted as dangerous and confusing, contributes to the dark mood of the novel and reinforces the dark tone of the novel. In the novel, Heathcliff's home in the English moors is named Wuthering Heights. According to the novel, the word "Wuthering" describes "the atmospheric tumult to which its station is exposed in stormy weather. Pure, bracing ventilation they must have up there at all times, indeed: one may guess the power of the north wind blowing over the edge, by the excessive slant of a few stunted firs at the end of the house; and by a range of gaunt thorns all stretching their limbs one way, as if craving alms of the sun." (Lockwood, Wuthering Heights, 1847) The strong house is like a castle or a dungeon which appears in most Gothic novels, and makes readers shiver before knowing what happen inside. The word "Wuthering" vividly deliver the terrible wild and windy weather on the moors. The whole Wuthering Heights is like an old decadent painting, cold and lifeless. W. Somerset Maugham includes Wuthering Heights in his ten most important novels, and here is how he remarks on the setting of the house, " 'Wuthering Heights' reminds me of one of the great paintings of EL Glico. In the painting, there is a view of the dark and ridiculous land under the dark clouds. The thunder is rumbling, and the long, sinister figures are smashing, and they are stunned by the emotions that are not in the world."

There are many descriptions of the weather in the novel too to indicate the horrible characters. When the narrator, Lockwood, arrives, Heathcliff emphasizes the dangerous landscape when he mentions the weather. $\mathrm{He}$ tells Lockwood, "I wonder you should select the thick of a snow-storm to ramble about in. Do you know that you run a risk of being lost in the marshes? People familiar with these moors often miss their road on such evenings; and I can tell you there is no chance of a change at present." (Heathcliff, Wuthering Heights, 1847) Lockwood, weather-bound, spends a terrifying night at Wuthering Heights. He can't understand the residents because of their inhospitable behavior, which parallels the inhospitable weather and setting. Other description of weather include when Heathcliff disappears a tree is struck by lightning; when Catherine is buried there is a storm; when Cathy decides to marry Edgar, there is another storm. All the lightening and storms express the feeling of the characters in the story and 
unfold a long scroll of the Gothic setting.

\subsection{Uncanny Plots and Supernatural Scenes}

One of the elements that make Gothic novels is the uncanny plots or supernatural scenes. When reading Gothic novels, we may encounter ghosts, mysterious apparitions, and unexplainable sounds or events, which is quite a thrilling yet exciting experience. H. P. Lovecraft once comments, "The oldest and strongest emotion of mankind is fear, and the oldest and strongest kind of fear is fear of the unknown." [9] The Mysteries of Udolpho, by Anne Radcliffe, is filled with themes of physical and psychological terror, including remote and crumbling castles, a dark villain, a persecuted heroine, and supernatural elements. In The Monk, there are the Bleeding Nun, the Wandering Jew, and the Devil. Mary Shelley set her scenes amid creepy sites such as graveyards, gloomy castles, and even created a grotesque monster who asks for a wife to emphasize the eerie plot of her novel Frankenstein. Gothic novels' attraction also comes from the genre's suggestion of supernatural or inexplicable events, such as inanimate objects coming to life, ghosts, spirits, and vampires like that of Bram Stoker's Dracula.

The first supernatural element the readers encounter is in the early Wuthering Heights, when Mr. Lockwood is bound by a snowstorm and has to stay overnight at Wuthering Heights. After having a nightmare, he finds his hand gripped by the ghost of Catherine Earnshaw, who asks him to let her in. Mr. Lockwood angrily complains to Heathcliff that she must have been a changeling in life, "she must have been a changeling - wicked little soul! She told me she had been walking the earth these twenty years: a just punishment for her mortal transgressions, I've no doubt!" (Lockwood, Wuthering Heights, 1847) In Irish and British mythology, a changeling is a mischievous fairy disguised as an infant or child who switches places with a human child. Lockwood means that Catherine's ghost is too capricious to have been human.

After a little walk away, Lockwood finds that Heathcliff is jealous of what he experiences. Rather than fearing and escaping from the ghost, Heathcliff begs her to come to him instead. Later, we learn that before she died, Catherine vowed to haunt Heathcliff, saying she wouldn't rest until he was in the grave with her. Immediately after her death, he begs her to do so, proclaiming his belief in ghosts and claiming that he cannot live without her. In the scene of Heathcliff's death, Heathcliff refuses all food and demands that he be left entirely alone. The next morning, at breakfast, Heathcliff terrifies Nelly when he seems to see an apparition. She can see nothing, but it seems to her that Heathcliff is communicating with it. It seems that Heathcliff is really haunted by Catherine, like he always wishes. When Heathcliff is found dead the next morning, the window is open and the corpse soaking wet: it's like he finally connects with the wet weather and Catherine. Heathcliff's all-consuming love and passion for Catherine is made clear through these supernatural scenes.

\section{CONCLUSION}

Gothic novels are called gothic novels because they have features of Gothic Architecture, they are dark, terrifying, and mysterious, and provide unlimited horrible and thrilling imagination and excitement. The author's background of growing up on the wild moors, the setting of the romance on the English northern moors, the crazy and unchained characters who show strong emotions, the merciless revenges, and the uncanny plots and the supernatural scenes all contributed to the fact that Wuthering Heights is a Gothic novel.

While except being a Gothic novel, the other merits or flaws and the author's intention of creating the novel are not mentioned in this article.

\section{REFERENCES}

[1] James Lorimer, The North British Review, 1847

[2] The Examiner, Jaunuary 8, 1848

[3] Emily Bronte, A Little While, a Little While (1846) Stanza vii

[4] Shorter, Clament K, Charlotte Bronte and Her Circle (1896), Westport: Greenwood, 1970

[5] Shorter, Clament K, Charlotte Bronte and Her Circle (1896), Westport: Greenwood, 1970

[6] Shorter, Clament K, Charlotte Bronte and Her Circle (1896), Westport: Greenwood, 1970

[7] Graham's Lady's Magazine, July, 1848

[8] Patterson's Magazine, March, 1848

[9] H. P. Lovecraft, "Supernatural Horror in Literature", The Recluse, No. 1 (1927) 